\title{
Degree Fahrenheit
}

National Cancer Institute

\section{Source}

National Cancer Institute. Degree Fahrenheit. NCI Thesaurus. Code C44277.

A unit of temperature of the temperature scale designed so that the freezing point of water is 32 degrees and the boiling point is 212 degrees, placing the boiling and melting points of water 180 degrees apart. One degree Fahrenheit is 5/9ths of a kelvin (or of a degree Celsius), and minus 40 degrees Fahrenheit is equal to minus 40 degrees Celsius. 